\title{
Exposure to low intensity ultrasound removes paclitaxel cytotoxicity in breast and ovarian cancer cells
}

\author{
Celina Amaya', Shihua Luo ${ }^{1}$, Julio Baigorri², Rogelio Baucells², Elizabeth R. Smith ${ }^{3}$ and Xiang-Xi Xu*
}

\begin{abstract}
Background: Paclitaxel (Taxol) is a microtubule-stabilizing drug used to treat several solid tumors, including ovarian, breast, non-small cell lung, and pancreatic cancers. The current treatment of ovarian cancer is chemotherapy using paclitaxel in combination with carboplatin as a frontline agent, and paclitaxel is also used in salvage treatment as a second line drug with a dose intensive regimen following recurrence. More recently, a dose dense approach for paclitaxel has been used to treat metastatic breast cancer with success.

Paclitaxel binds to beta tubulin with high affinity and stabilizes microtubule bundles. As a consequence of targeting microtubules, paclitaxel kills cancer cells through inhibition of mitosis, causing mitotic catastrophes, and by additional, not yet well defined non-mitotic mechanism(s).

Results: In exploring methods to modulate activity of paclitaxel in causing cancer cell death, we unexpectedly found that a brief exposure of paclitaxel-treated cells in culture to low intensity ultrasound waves prevented the paclitaxel-induced cytotoxicity and death of the cancer cells. The treatment with ultrasound shock waves was found to transiently disrupt the microtubule cytoskeleton and to eliminate paclitaxel-induced rigid microtubule bundles. When cellular microtubules were labelled with a fluorescent paclitaxel analog, exposure to ultrasound waves led to the disassembly of the labeled microtubules and localization of the signals to perinuclear compartments, which were determined to be lysosomes.

Conclusions: We suggest that ultrasound disrupts the paclitaxel-induced rigid microtubule cytoskeleton, generating paclitaxel bound fragments that undergo degradation. A new microtubule network forms from tubulins that are not bound by paclitaxel. Hence, ultrasound shock waves are able to abolish paclitaxel impact on microtubules. Thus, our results demonstrate that a brief exposure to low intensity ultrasound can reduce and/or eliminate cytotoxicity associated with paclitaxel treatment of cancer cells in cultures.
\end{abstract}

Keywords: Ultrasound wave, Microtubule, Taxol/paclitaxel, Cytotoxicity, Lysosomal degradation, Ovarian cancer, Breast cancer

\footnotetext{
*Correspondence: xxu2@med.miami.edu

'Department of Radiation Oncology, Sylvester Comprehensive Cancer Center, University of Miami Miller School of Medicine, Papanicolaou Building, Room 415 [M877], 1550 NW 10th Avenue, Miami, FL 33136, USA

Full list of author information is available at the end of the article
}

(C) The Author(s). 2021 Open Access This article is licensed under a Creative Commons Attribution 4.0 International License, which permits use, sharing, adaptation, distribution and reproduction in any medium or format, as long as you give appropriate credit to the original author(s) and the source, provide a link to the Creative Commons licence, and indicate if changes were made. The images or other third party material in this article are included in the article's Creative Commons licence, unless indicated otherwise in a credit line to the material. If material is not included in the article's Creative Commons licence and your intended use is not permitted by statutory regulation or exceeds the permitted use, you will need to obtain permission directly from the copyright holder. To view a copy of this licence, visit http://creativecommons.org/licenses/by/4.0/ The Creative Commons Public Domain Dedication waiver (http://creativecommons.org/publicdomain/zero/1.0/) applies to the data made available in this article, unless otherwise stated in a credit line to the data. 


\section{Introduction}

Paclitaxel $\left(\mathrm{Taxol}^{\circ}\right)$ is an important component of the chemotherapeutic regime for several solid tumors, including those of lung, breast, prostate, ovary, and Kaposi's sarcomas [1-5]. Paclitaxel was first developed and approved for use in treating ovarian carcinomas [5, 6], and it is still a key drug in the current management of ovarian cancer, used as a frontline agent in combination with platinum-containing drugs, such as carboplatin and cisplatin [7], and also in salvage treatment as a second line drug with a dose intensive regimen following recurrence [8-11]. Paclitaxel generally is highly effective with tolerable side effects, but sensory peripheral neuropathy, presenting as numbness and pain of feet and hands, is often the dose-limiting toxicity of the agent [12-15]. Although attempts have been explored to reduce or prevent damage to the extremities, such as hypothermia cooling gloves and socks [16, 17], currently no effective or satisfactory methods or drugs are available to reverse this daunting side effect $[18,19]$. Similarly, alopecia (hair loss) is another detrimental side effect of paclitaxel chemotherapy [20-22].

Paclitaxel binds tightly to the beta-tubulin protein within microtubules, and stabilizes the microtubule filaments $[2,23,24]$. This stabilization of microtubules interferes with microtubule dynamics and leads to growth arrest and subsequently apoptosis [2, 25, 26], which is thought to underlie the anti-cancer mechanism of action. Paclitaxel has also been shown to induce aberrant multipolar division in mitosis, leading to chromosome mis-segregation and subsequently apoptotic cell death $[27,28]$. Because it targets microtubule function in mitosis, paclitaxel is generally considered a microtubule stabilizing and anti-mitotic cancer drug [2, 29]. However, non-mitotic targeting of paclitaxel mechanisms are also suggested [30-33]. Factors related to microtubule dynamic stability appear to underlie the sensitivity and resistance of cancer cells to paclitaxel [1, 34, 35].

Ultrasound technologies have extensive applications in medicine, either for diagnosis (sonogram) or therapy [36-38]. Typically, ultrasound with extremely low intensity $\left(1-50 \mathrm{~mW} / \mathrm{cm}^{2}\right)$ and high frequency $(3-5 \mathrm{MHz})$ is used for diagnostic (imaging) purposes. High intensity $\left(>8 \mathrm{~W} / \mathrm{cm}^{2}, 20-60 \mathrm{kHz}\right)$ ultrasound that can deliver strong energy is used for surgery and disruption through heating and acoustic cavitation. The medical application of ultrasound with an intensity that is low yet sufficiently high to produce biological activity is known as ultrasound physiotherapy [38], which uses a sufficiently strong but non-disruptive ultrasound shock waves (0.5$3.0 \mathrm{~W} / \mathrm{cm}^{2}$ ) [38-40]. The most commonly used devices produce ultrasound waves with frequencies either around $1 \mathrm{MHz}$ or $20-150 \mathrm{kHz}$ (known as long wavelength ultrasound). Several studies report similar effects by either $1-3 \mathrm{MHz}$ or $45 \mathrm{kHz}$ ultrasound waves on cells and tissues $[41,42]$. The majority of ultrasound in medical application of physiotherapy is using the frequency in the range of $1-3 \mathrm{MHz}$, which traditionally is thought to produce less cavitation and thus tissue damage. However, more recent laboratory findings indicate that the low frequency (20 to $100 \mathrm{KHz}$ ) ultrasound seems to produce a stronger biological impact [42-44], and at the same time seems to produce no cell and tissue damage [45-47]. With the development of better low frequency ultrasound devices [48], the use of low frequency ultrasound for medical procedure gains interests [49], improving cardia function $[46,50]$, and treating neuropathy-induced ulcers [51]. The new development in ultrasound physiotherapy provides rationale to study the impact of low frequency ultrasound waves on cells.

Many of the studies attribute the physiological activities of ultrasound waves to heating; however, nonheating effects, such as changes in gene expression, mechanical transduction, and release of cytokines, have also been noted [43, 44, 52]. In particular, ultrasound disrupts the cellular cytoskeleton [53-55]. The force transduced by ultrasound can transiently disrupt actin and microtubule cytoskeletons, which then reassemble without significant impact on cell structure and survival [53-56]. Studies also found that low intensity ultrasound caused chromosomal damage and DNA breaks [57]. Focused, low intensity ultrasound may also be useful for targeting tumors [58].

Our initial experimental rationale was to test if low intensity ultrasound could cause DNA damage and synergize with paclitaxel, replacing the use of a platinum agent in chemotherapy. Unexpectedly, however, we found that ultrasound treatment can effectively and completely neutralize the cytotoxic effect of paclitaxel on cells in culture. Based on the results, we conclude that a brief exposure of low intensity ultrasound can reverse paclitaxel-induced cytotoxicity in cancer cells, and provide a possible mechanism.

\section{Methods \\ Reagents}

Taxol/paclitaxel were purchased from Sigma-Aldrich, Inc., and the dry powder was prepared for $100 \mu \mathrm{M}$ stock solutions in DMSO. Tissue culture flasks (trade mark Falcon), tissue culture media, trypsin, and 100X antibiotic-antimycotic solution (Cellgro, Mediatech, Inc) were purchased from VWR Inc. (Springfield, NJ). Alexa Fluor 488 and 555 conjugated secondary antibodies were purchased from Life Sciences Inc. (Eugene, Oregon) for use in immunofluorescence microscopy. Primary antibodies: anti-Lamin A (1:400, H-102, rabbit polyclonal IgG); mouse monoclonal anti-Lamin B (1:300, sc373918); and goat polyclonal anti-Lamin B (1:400, 
sc6216) were from Santa Cruz Biotechnology Inc.; rabbit polyclonal anti-Lamin B1 (1:1000, ab16048) and mouse monoclonal anti- $\alpha$ Tubulin $(1: 500,66,031)$ were from Abcam and Proteintech, respectively. Mouse monoclonal anti-alpha-tubulin, were purchased from Sigma-Aldrich, Inc. (St. Louis, MO). More details of the reagents used are also reported previously [59-62].

\section{Cell culture}

Ovarian cancer cells including MCF 7, MDA-MB-231, A2780, purchased from ATCC (American Tissue Culture Collection), and OVCAR3, $-4,-5,-8$, and -10 originally obtained from Hamilton lab $[59,60]$ were used in the experiments. These cells were cultured in RPMI1640 media supplemented with $10 \%$ fetal bovine serum and $1 \mathrm{X}$ penicillin/streptomycin, as described previously $[59,61,62]$. For serum-free experiments, cells were cultured in RPMI with 1\% BSA and 1X penicillin/streptomycin. All cells were maintained at $37^{\circ} \mathrm{C}$ in a humidified atmosphere of $5 \% \mathrm{CO}_{2}$.

\section{Ultrasound exposure}

We have acquired and tested both the bath and probe types of ultrasound devices for our study (Fig. 1a). The bath device produces 45 or $150 \mathrm{kHz}, 1-3 \mathrm{~W} / \mathrm{cm}^{2}$ ultrasound waves with adjustable frequency and energy levels (Crest PowerSonic P1100 Model, US Ultrasonics. LLC, Richmond VA USA).

Cells were plated on 6-well tissue culture plates, and cultured with $0.5 \mathrm{ml}$ of medium. For treatment with ultrasound, the tissue culture plate was placed on the surface of the water bath with a temperature of the bath set at $35^{\circ} \mathrm{C}$. Using a costumed-make manifold that holds the dish and fitted on the ultrasound bath, the tissue culture plate was immersed in the bath with the bottom of the plate around $2-3 \mathrm{~mm}$ under water surface. Generally, the power level was set at $1 \mathrm{~W} / \mathrm{cm}^{2}$. Immediately following exposure to ultrasound, the plate was placed back into cell culture incubator.

\section{Cell proliferation assay}

Cell numbers were determined using an WST-1 cell proliferation kit from Roche. Briefly, at the determined time points, the cell culture medium was replaced with freshly prepared reaction buffer composed of DMEM/F12 media containing 10\% WST-1 solution and incubated at $37^{\circ} \mathrm{C}$ for $1 \mathrm{~h}$. The absorbance at $450 \mathrm{~nm}$ of the media measures the accumulation of the soluble formazan dye produced by viable cells, which correlates with relative cell number of the same cell types.

\section{Immunofluorescence microscopy}

The procedure has been described previously [62-64]. Briefly for immunofluorescence microscopy, adhered cells on glass coverslips were washed twice with PBS at room temperature, fixed with $4 \%$ paraformaldehyde for $15 \mathrm{~min}$, and permeabilized with $0.1 \%$ Triton X-100 for 5 min. Then, the cells were washed three times with PBS, blocked with 5\% BSA in PBS containing 0.1\% Tween-20 for $1 \mathrm{~h}$, and incubated overnight at $4{ }^{\circ} \mathrm{C}$ with primary

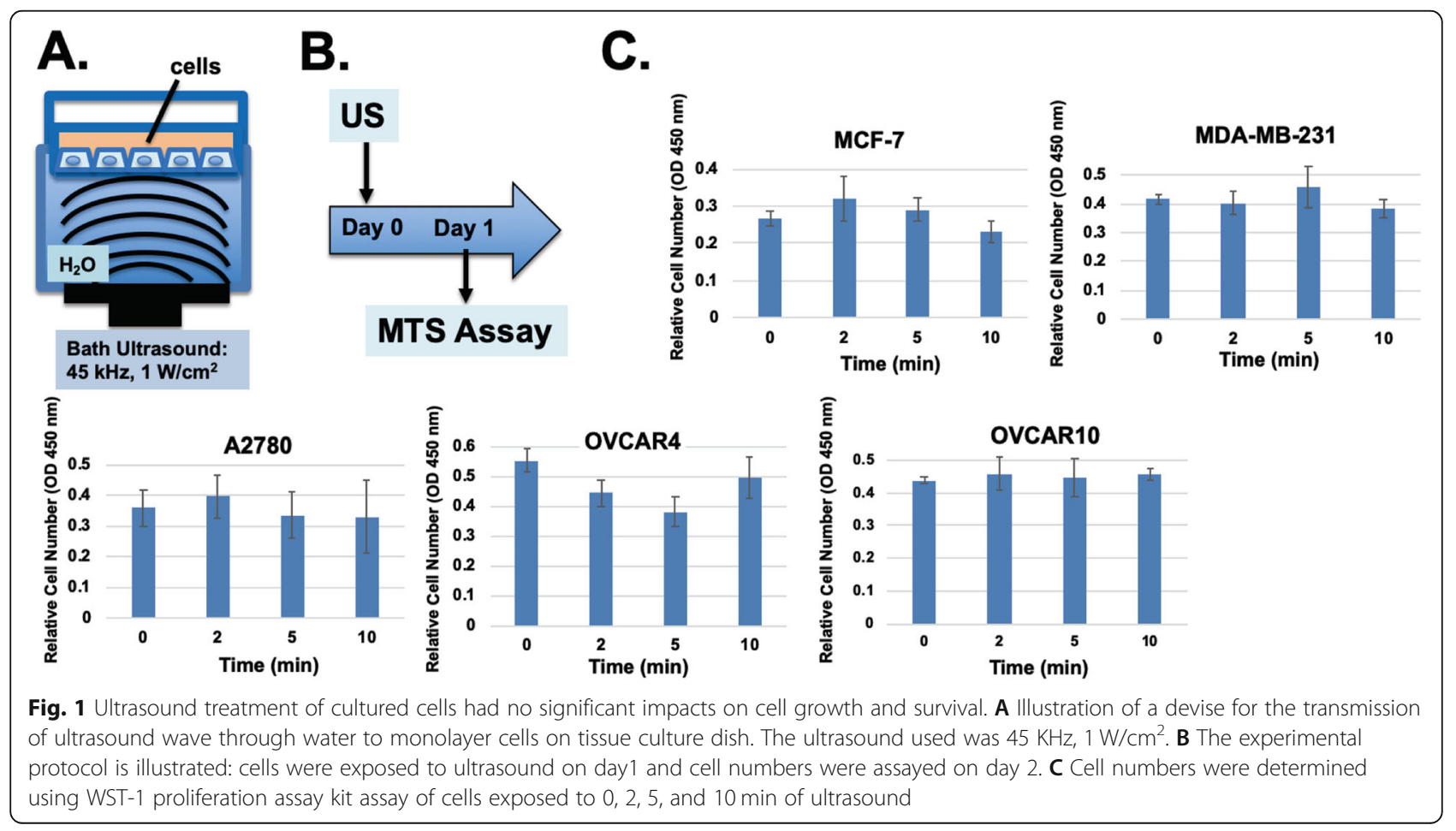


antibodies in 5\% BSA in PBS. AlexaFluor 488conjugated (green fluorescence) or AlexaFluor 555conjugated (red fluorescence) secondary antibodies were used. Cells were washed three times, counterstained with DAPI, then mounted and sealed in ProLong Gold antifade reagent (Thermo Fisher Inc). Immunofluorescence was viewed using a $100 \mathrm{X}$ objective lens on Zeiss Axio Observer Z1 using AxioVision software.

\section{Results}

\section{A brief exposure to low intensity ultrasound does not} affect cancer cell survival and growth in culture

We performed initial testing of ultrasound of both 1 $\mathrm{MHz}$ and $45 \mathrm{kHz}$ on modulating paclitaxel treatment of cancer cells in cultures. Although either ultrasound frequency produced similar effects on cell survival, the long wavelength ultrasound appeared to give a stronger and consistent impact with similar intensity, consistent with that reported [42]. Thus, we chose to focus on our first study using the $45 \mathrm{kHz}$ ultrasound set up.

First, we examined the effect of low frequency low intensity ultrasound exposure on survival of monolayer cells in tissue culture dishes with a water bath ultrasound set up (Fig. 1a). Several lines of breast (MCF7, MDA-MB-231) and ovarian (A2780, OVCAR3, OVCAR4, OVCAR5, OVCAR10) cancer cells were plated as monolayers in 6-well culture dishes at around $70 \%$ density with $2 \mathrm{ml}$ of medium per well covering the cells. The tissue culture plate was hold with a manifold that submerged the plate with the bottom at a level approximately 2 to $3 \mathrm{~mm}$ beneath the water surface of the bath sonicator. Here the temperature of the water bath was set to $35^{\circ} \mathrm{C}$ to prevent potentially heating over $37^{\circ} \mathrm{C}$, and the ultrasound frequency was set at $45 \mathrm{kHz}$, with an energy output of $1 \mathrm{~W} / \mathrm{cm}^{2}$. Following a brief ultrasound exposure, the tissue culture dishes were placed back into tissue culture incubator and the cell number was determined by WST-1 proliferation assay 1 day after ultrasound exposure (Fig. 1b).

Exposure of cells to $45 \mathrm{kHz}$ ultrasound for 2 to $10 \mathrm{~min}$ had no major effect on cell survival and proliferation measured 1 day after exposure in all cell line tested (Fig. 1c). The ultrasound treatment did not alter the temperature of the culture medium. Additional experiments also confirmed that cell numbers were not affected 2 day after ultrasound treatment (not shown). In some lines (A2780), a fraction (around 10\%) of cells appeared to detach from the culture dish after a 10-min exposure to ultrasound immediately after treatment; however, the treatment had no significant impact on cell survival and growth. Presumably, the cells re-attached and continue to grow. Thus, a brief exposure of ultrasound alone did not affect cells in culture. However, it was noted that prolong exposure to ultrasound such as $15 \mathrm{~min}$ or longer resulted in increased detachment of cells from the culture plate and progressively loss of cell viability. Especially, higher ultrasound intensity (such as $3 \mathrm{~W} / \mathrm{cm}^{2}$ ) with longer exposure also significantly reduced cell survival.

\section{A brief exposure to low intensity ultrasound eliminates paclitaxel cytotoxicity in breast and ovarian cancer cells in cultures}

In an initial experiment with an intend to determine the potential synergistic effect of paclitaxel and low intensity ultrasound in killing ovarian cancer cells, we observed a surprising result that actually ultrasound reversed the cytotoxicity of paclitaxel (Fig. 2). The concerntrations of paclitaxel used in studying cancer cells in cultures are generally to be in a range between 0.1 to $100 \mathrm{nM}$, and we have recently determined the the dosage for $50 \%$ cell killing was around $0.3 \mathrm{nM}$ [64]. Thus, we chose a concerntration of $1 \mathrm{nM}$ paclitaxel to be used in the current experimental settings. In the experiments, paclitaxel was added to cells in culture for a total of 3 days, and a 5min ultrasound treatment was performed on day 1 , following 2 days in culture before determination of cell number (Fig. 2a). In the absence of paclitaxel, ultrasound exposure had little effect on cell number by the end of day 3. As expected, paclitaxel treatment of the ovarian and breast cancer cells by severely reduced cell numbers to approximately $10-25 \%$ of control (Fig. 2b). However, the cell numbers measured at the end of day 3 were higher in all lines when the paclitaxel treated cells were exposed to ultrasound for $5 \mathrm{~min}$ on day 1 (Fig. 2b). Surprisingly, ultrasound treatment appeared to reduce or remove the inhibitory effect of paclitaxel.

We also performed the experiments in a slightly different protocol; that medium was changed at day 1 to fresh medium without paclitaxel, prior to ultrasound exposure (Fig. 2c). Replacing paclitaxel containing medium to fresh medium without paclitaxel after 1 day had little changes in the cytotoxicity of paclitaxel observed at day 3 (Fig. 2d), indicating the impact of paclitaxel after incubation for 1 day lingered to day 3. This phenomenon is previously known, that a short-term exposure of cancer cells to paclitaxel produced persistent growth inhibitory activity [65]. Ultrasound exposure for $5 \mathrm{~min}$ was also able to reverse cytotoxicity from the one-day exposure of paclitaxel, suggesting the impact of ultrasound was to remove the lingering activity of paclitaxel for cell killing on day 2 and 3 (Fig. $2 \mathrm{~d}$ ).

Thus, the results indicate that paclitaxel exposure for $24 \mathrm{~h}$ is sufficient to kill cells over the next 2 days without the need for paclitaxel in the medium, and ultrasound exposure reduces the effect of paclitaxel activity retained in the cells from the initial exposure. 

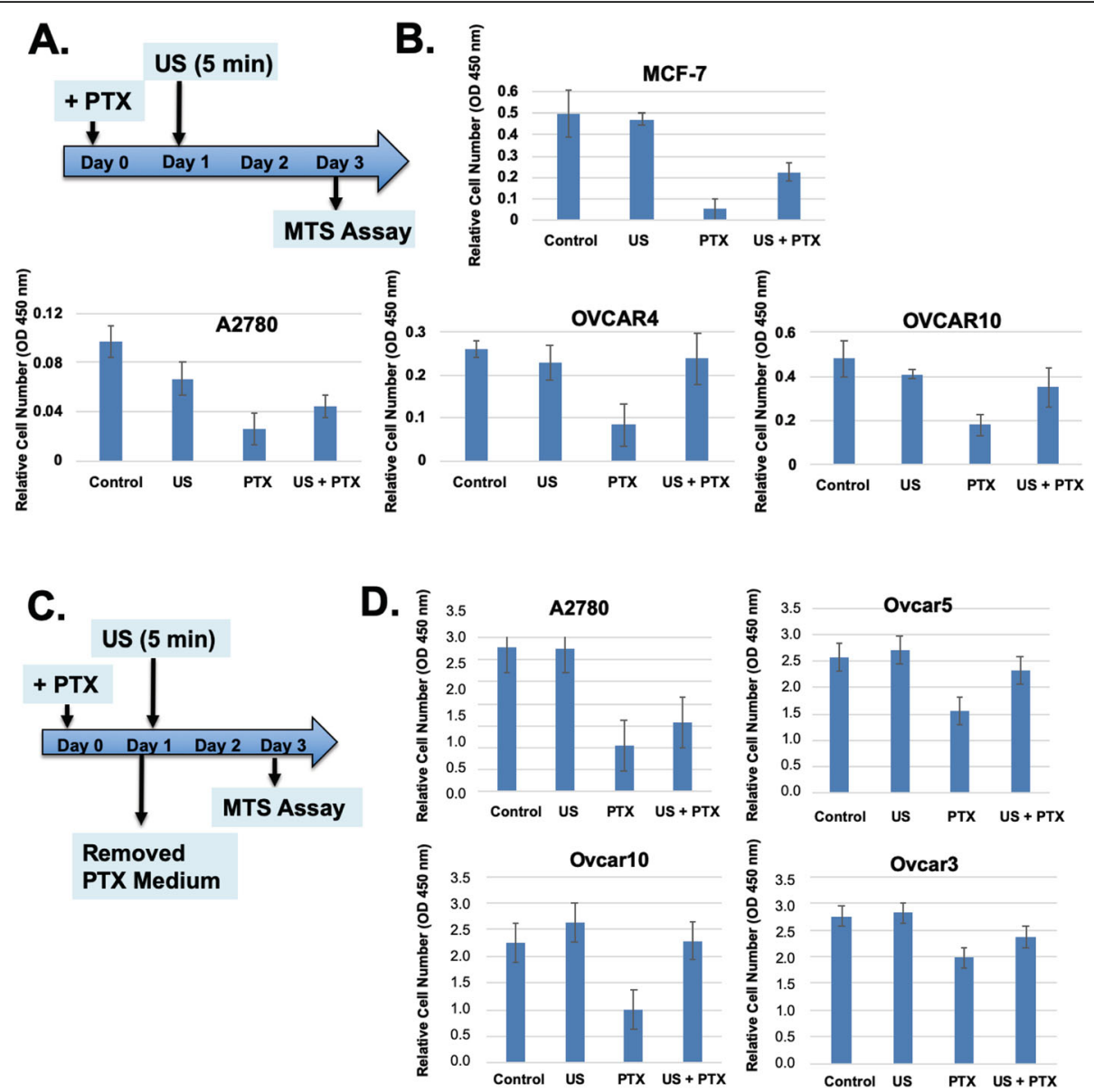

Fig. 2 Paclitaxel mediated cell killing and reversal by ultrasound in the absence of continuous exposure to extracellular paclitaxel. A The experimental protocol is illustrated. B Ovarian cancer cells were treated with or without paclitaxel (1 nM, + PTX), and in next day, the cells were exposed to ultrasound for $5 \mathrm{~min}$. In $48 \mathrm{~h}$, the cell number were determined by WST-1 assay with triplicate samples. The error bars represent standard deviations. The differences in cell numbers between PTX and PTX + US are statistically significant determined by Student's T-test. The $p$ values are 0.009, 0.007, and 0.015 for MCF-7, OVCAR4, and OVCAR10 respectively. C The experimental protocol is illustrated. The protocol is similar to those presented above. However, paclitaxel in the medium was removed before ultrasound exposure at Day 1. D Breast and ovarian cancer cells were treated with or without paclitaxel (1 nM, + PTX), and in about $24 \mathrm{~h}$, the medium was changed and the cells were exposed to ultrasound (+ US, $45 \mathrm{KHz}, 1 \mathrm{~W} / \mathrm{cm} 2)$ for $5 \mathrm{~min}$. At day 3 , the cell numbers were determined by WST-1 assay with triplicate samples. The differences in cell numbers between PTX and PTX + US are statistically significant with $p$ value of $0.07,0.02,0.007$, and 0.07 for A2780, OVCAR5, OVCAR10, and OVCAR3 respectively, determined by Student's T-test

Reversal of paclitaxel cytotoxicity depends on timing and schedule of ultrasound exposure

The observation that ultrasound treatment reduced paclitaxel cytotoxicity was rigorously repeated and determined to be robust, though sensitive to schedules and timing of ultrasound exposure. We designed experiments with various schedules of ultrasound exposure to determine the optimal time to reverse paclitaxel cytotoxicity and to understand mechanisms (Fig. 3). In one set of experiments when ultrasound was given $4 \mathrm{~h}$ after paclitaxel and over a 3-day time course (Fig. 3a), there was no difference on cell numbers compared to paclitaxel alone, indicating no rescue (Fig. 3b). When delivered on day 2, ultrasound also did not alter paclitaxel cytotoxicity (Fig. 3c,d). Instead, the optimal time to administer ultrasound to reverse paclitaxel inhibition of cell proliferation was found to be 8 to $24 \mathrm{~h}$ after paclitaxel was added. The experiments were repeated and performed in multiple cell lines, with results supporting that reversal of paclitaxel cytotoxicity by a brief exposure to ultrasound is reproducible, although the dosage of paclitaxel and the timing of ultrasound exposure influence the degree of activity.

\section{Ultrasound shock wave causes transitory disruption of the microtubule cytoskeleton}

Low intensity ultrasound is known to disrupt the microtubule cell cytoskeleton [53-56]. Indeed, we confirmed that a brief exposure of ultrasound disrupted microtubules, although the structure reformed within hours. An experiment is shown in Fig. 4a, in which cells were 


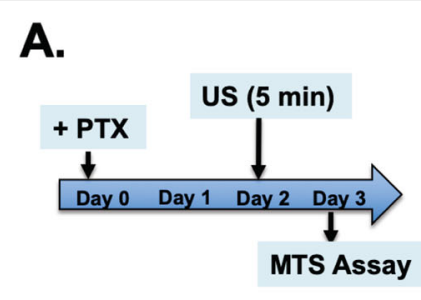

B.
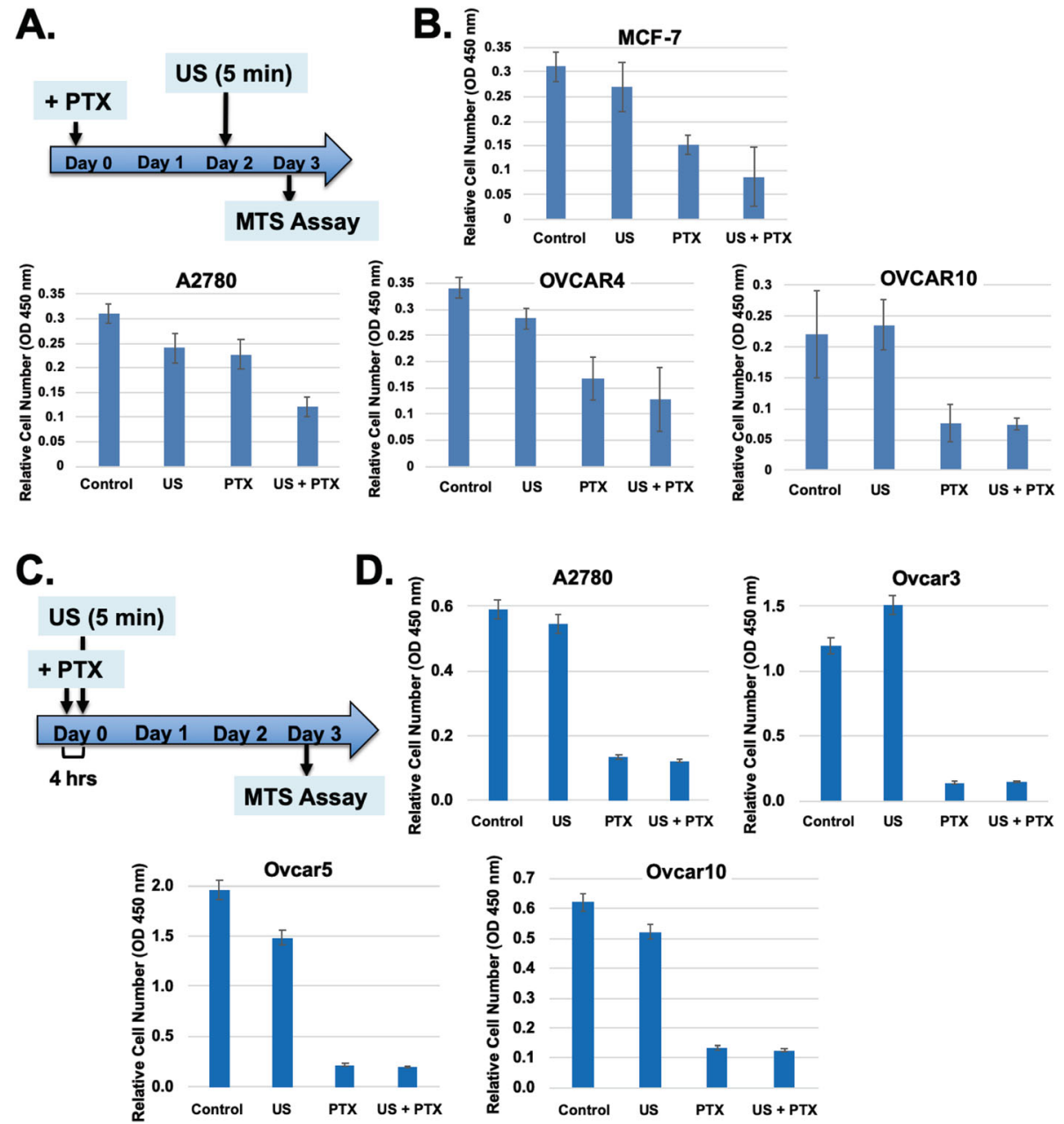

Fig. 3 Paclitaxel mediated cell killing and reversal by ultrasound depends on schedule and timing. A The experimental protocol is illustrated. Ultrasound was applied to the cells at Day 2 of paclitaxel treatment. B Breast and ovarian cancer cells (MCF-7, A2780, OVCAR4, OVCAR10) were treated with or without paclitaxel and ultrasound, and cell number was determined on Day 3. C The experimental protocol is illustrated: ultrasound was applied to the cells $4 \mathrm{~h}$ after paclitaxel treatment. D Ovarian cancer cells (A2780, OVCAR33, OVCAR5, OVCAR10) were treated with or without paclitaxel and ultrasound, and cell number was determined on Day 3. The standard deviations are presented as error bars. The differences in cell numbers between PTX and PTX + US are statistically not significant $(P>0.07)$ determined by Student- $T$ test, for all cell lines tested

treated with paclitaxel for $8 \mathrm{~h}$, then were exposed to ultrasound for $5 \mathrm{~min}$, and cell number was determined in day 3. Here, paclitaxel treatment greatly reduced the cell number determined after 3 days (Fig. 4b), though an exposure to ultrasound nearly completely prevented cell death or suppression of growth (Fig. 4b). Paclitaxel treatment resulted in the intense immunostaining of microtubule filaments, which was abolished by low intensity ultrasound (Fig. 4c). Here, the staining of microtubules was performed $2 \mathrm{~h}$ after ultrasound exposure, when the microtubule cytoskeleton had reformed. The microtubule cytoskeleton in paclitaxel and then ultrasound treated cells appeared to share the same morphology as control (no paclitaxel) cells, even though paclitaxel was not removed from the medium (Fig. 4c). Thus, we were able to use setting of ultrasound with nearly no impact on cell viability and growth but with complete reversion of paclitaxel cytotoxicity (Fig. 4).

We also observed that paclitaxel-induced microtubule bundling persisted over $48 \mathrm{~h}$ (Fig. 5a). In contrast, ultrasound treatment eliminated paclitaxel-induced microtubule bundles in the cells over the next $24 \mathrm{~h}$ (Fig. 5a).

A careful examination of the microtubule network immediately and over time after ultrasound treatment showed that ultrasound only subtly altered microtubules as detected by alpha-tubulin immunostaining (Fig. 5b). The staining appeared slightly more diffuse immediately (5 min) after ultrasound treatment (Fig. 5b), although microtubule bundles were still present. Subsequently, from 15 to $60 \mathrm{~min}$ after ultrasound of the cells, alphatubulin-stained spots appeared (Fig. 5b). The spots then faded away in next 1-2 $\mathrm{h}$ (such as seen in Fig. 4b). 


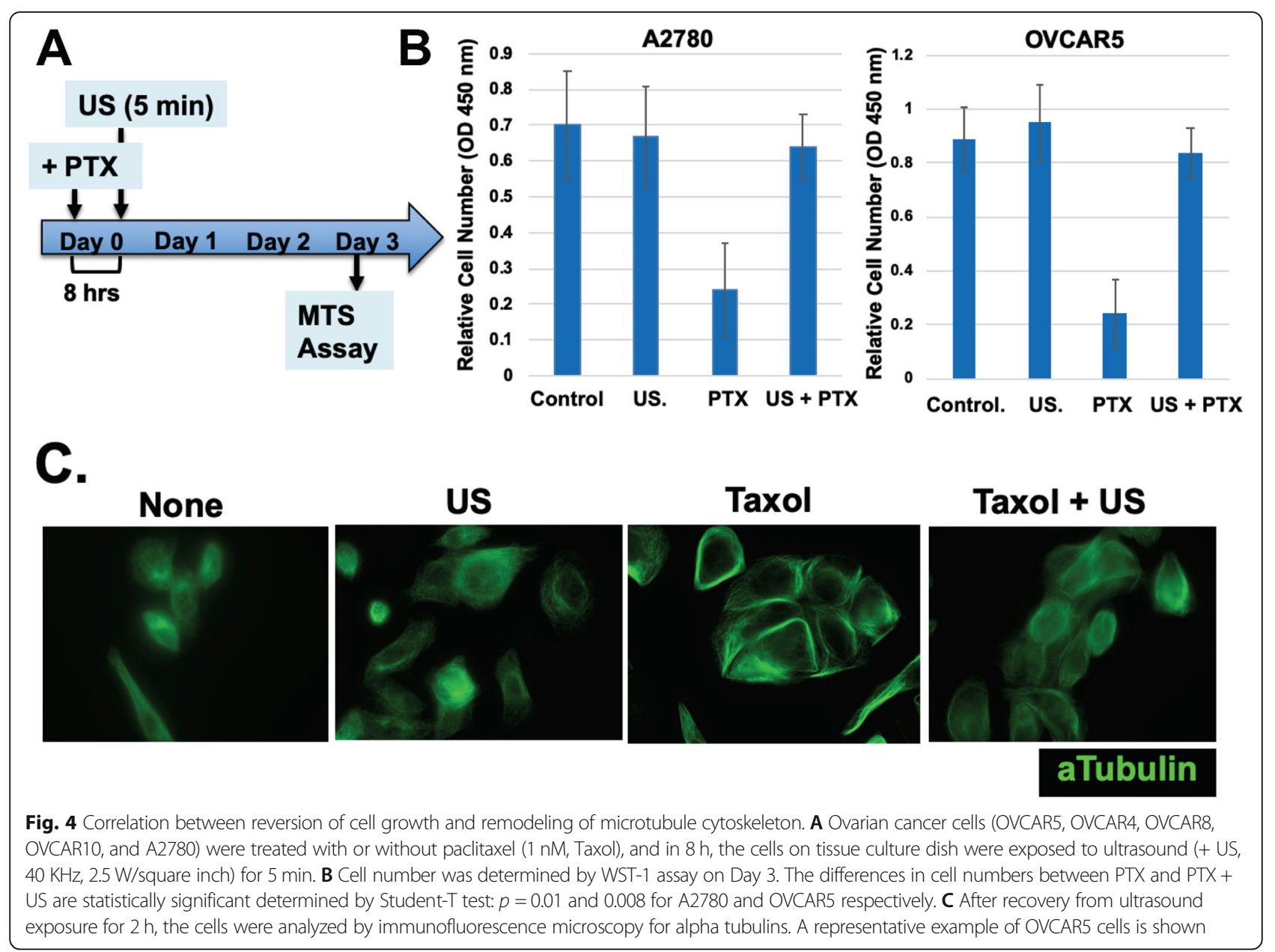

Lysosomal degradation of paclitaxel analogs labeled microtubules following exposure to ultrasound shock wave We examined the effects of ultrasound on the microtubule cytoskeleton by immunofluorescence microscopy using a fluorescence-labeled paclitaxel analog (488-PTX) (Oregon Green $^{\mathrm{Tm}} 488$ Taxol, from ThermoFisher). Within 30 min after 488-PTX was added to cultures, the fluorescence signals uniformly labeled the microtubule cytoskeleton (Fig. 6a, control; Fig. 6b, 0 time). Without further perturbation, the fluorescence labels on cellular microtubules persisted, at the least for $24 \mathrm{~h}$. We found that a brief ultrasound treatment disrupted irreversibly the paclitaxel-labeled microtubule network. The fluorescence signals initially became diffuse, then the fluorescent molecules (presumably paclitaxel-bound tubulin or microtubule fragments) subsequently formed spots, which were identified as lysosomes using the lysosome marker, BioTracker LYSO-TP Live Cell Dye (from Millipore/Sigma) (Fig. 6).

Comparing to alpha-tubulin immunostaining staining, it appeared that nearly all the fluorescence Taxol-labeled microtubules were irreversibly disrupted by a brief exposure to ultrasound (Fig. 6a,b). In 30 to $60 \mathrm{~min}$ following ultrasound treatment, essentially all the fluorescence signals fated, while the labels on untreated cells retained. Thus, the elimination of paclitaxel bound microtubules seemed to correlate with the reversal of paclitaxel cytotoxicity.

The analyses of low intensity ultrasound in disrupting microtubules and reduction of paclitaxel cytotoxicity in cultured cells were first observed 3 years ago, and the lab has continued the investigation over the years in multiple cell lines. Only representative results are shown here, and a few results are included as supplementary figures. The impact of the low intensity ultrasound appears to be very robust and reproducible. Although subtle differences in timing. Degree of responses, and behaviors between different cell lines were observed, the general conclusion that low intensity ultrasound disrupt microtubules and reduce/ eliminate paclitaxel cytotoxicity is applicable to all lines.

\section{Discussion}

In this study, we have made a surprising discovery that ultrasound treatment can effectively and nearly completely neutralize the cytotoxic effect of paclitaxel on 


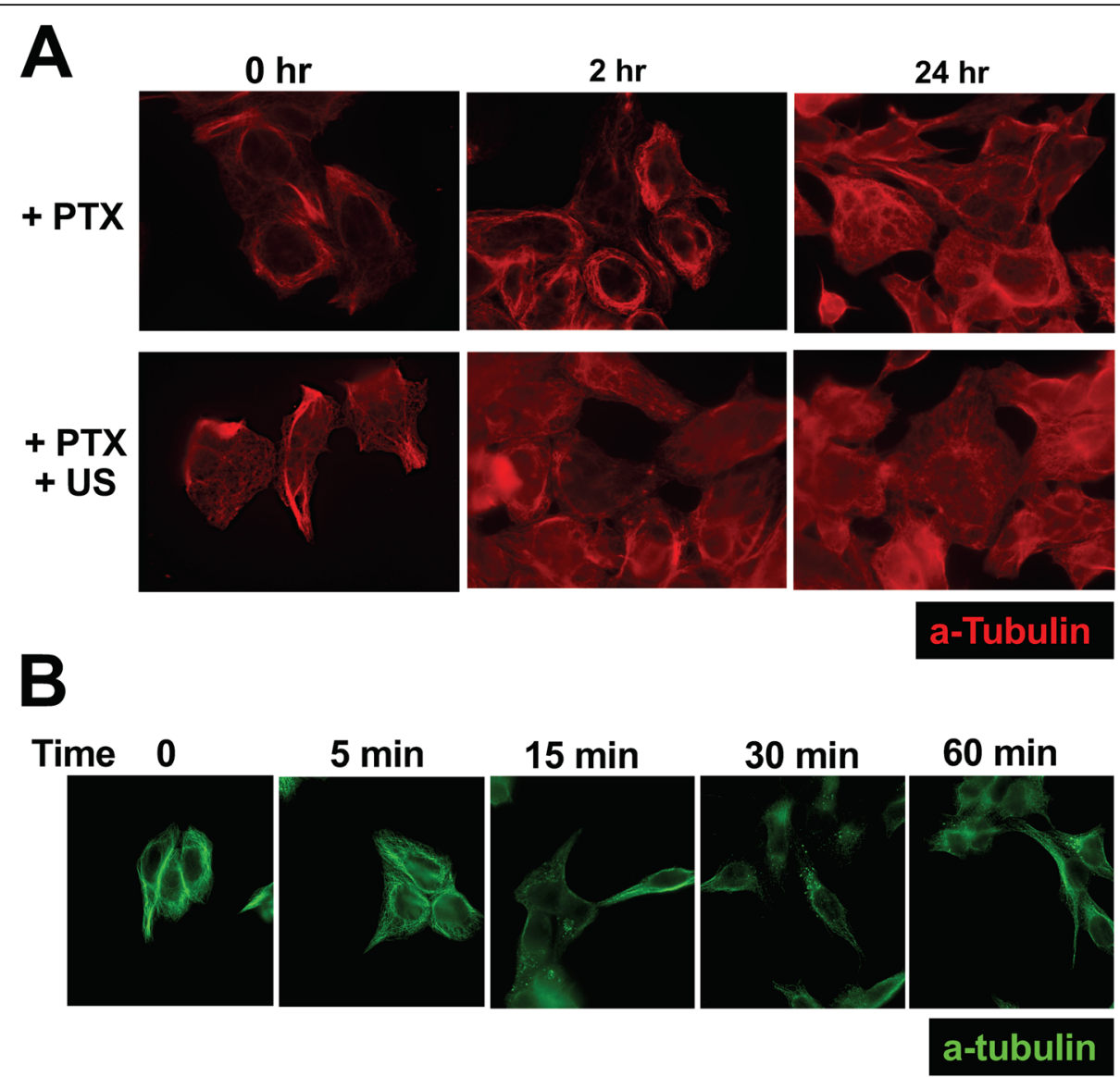

Fig. 5 Impacts of paclitaxel and ultrasound on microtubule filaments. A Breast and ovarian cancer cells (MCF-7, OVCAR3,OVCAR5, OVCAR4, OVCAR8, OVCAR10, and A2780) were treated with paclitaxel (1 nM, Taxol), and in $8 \mathrm{~h}$, the cells on tissue culture dish were exposed to ultrasound (+ US, $40 \mathrm{KHz}, 1 \mathrm{~W} / \mathrm{cm}^{2}$ ) for $5 \mathrm{~min}$. Following ultrasound treatment, at 0.2 , and $24 \mathrm{~h}$, the cells were fixed and processed for immunostaining for alpha-tubulin. An example of OVCAR5 cells is shown. B Cells were treated with paclitaxel ( $1 \mathrm{nM}$, Taxol), and in $8 \mathrm{~h}$, the cells on tissue culture dish were exposed to ultrasound $\left(+\mathrm{US}, 40 \mathrm{KHz}, 1 \mathrm{~W} / \mathrm{cm}^{2}\right.$ ) for $5 \mathrm{~min}$. Following ultrasound treatment, at 0, 5, 15, 30 and 60 min, the cells were fixed and processed for analyses by immunofluorescence microscopy for alpha tubulins. A representative example of A2780 cells is shown

cells in culture. Thus, we have discovered a technology and procedure in locally reversing paclitaxel cytotoxicity.

Our results confirm that low intensity ultrasound transiently disrupts the microtubule cytoskeleton, which can reform rapidly [53-56]. However, we speculate that ultrasound waves break the rigid, paclitaxel-bound microtubules into small filaments or individual tubulins that are still bound to paclitaxel. The unbound tubulin monomers likely form a new cytoskeleton during the recovery from ultrasound disruption. The paclitaxel-bound tubulins, either as fragments of broken microtubule filaments or as tubulin heterodimers/monomers, relocate to lysosomes for degradation.

Ultrasound physiological therapies have been widely used in various treatments of medical conditions including pain relief, wound healing, etc. [38-40]. Anecdotal accounts support many of the reported biological and therapeutic effects; however, more rigorous clinical trials have not established true biological activity over placebo effects [36, 37]. The scientific basis is not strong to support the claim for efficacy in application of low intensity ultrasound in medical procedures. In general, popular commercialized physiotherapy practices do show that low intensity ultrasound does not cause significant inverse effect and is relatively safe.

We have also briefly tested ultrasound of higher frequency ( 1 and $3 \mathrm{MHz}$ ) for their activity in reversing paclitaxel cytotoxicity. The initial finding was that ultrasound waves with higher frequency were also capable of breaking rigid microtubules and reducing paclitaxel-induced cell death. However, the activity of 1 and $3 \mathrm{MHz}$ ultrasound seemed to be less effective than the long wavelength $(45 \mathrm{KHz})$ ultrasound in the limited preliminary testings. Thus, a careful comparison of ultrasound of long wavelength to higher frequency for their ability to break paclitaxel-induced rigid microtubules and reduce cytotoxicity should be performed in the future. Likely, an optimal setting to 


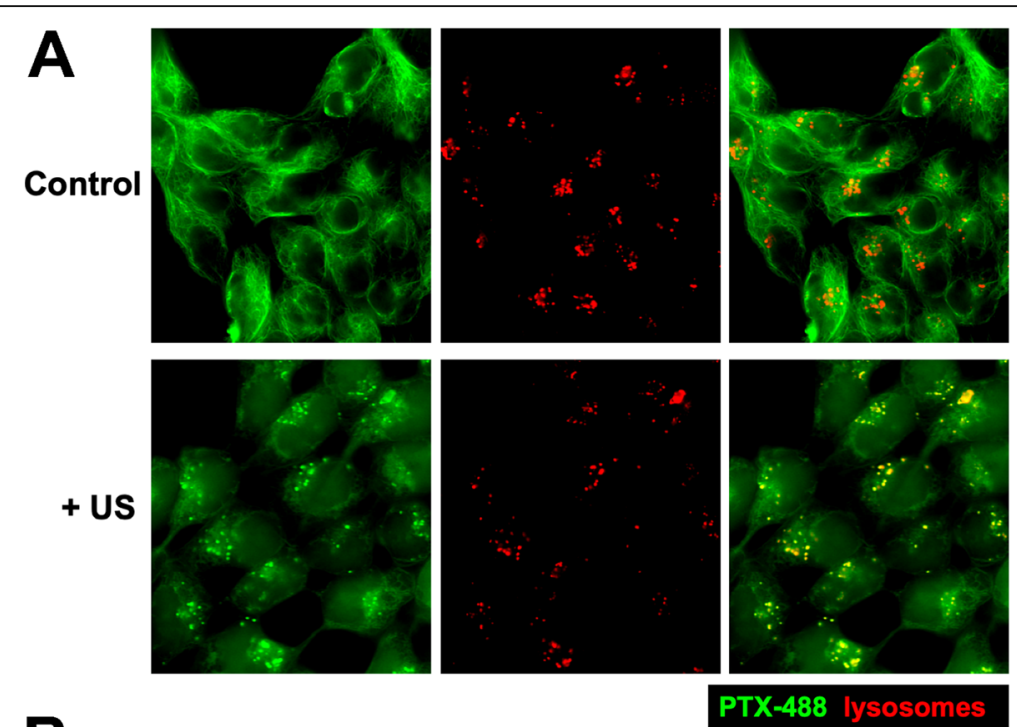

B
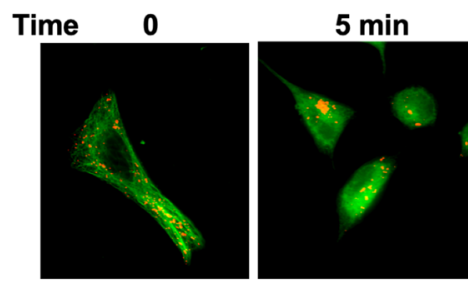

$10 \mathrm{~min}$

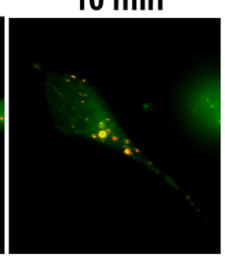

$30 \mathrm{~min}$
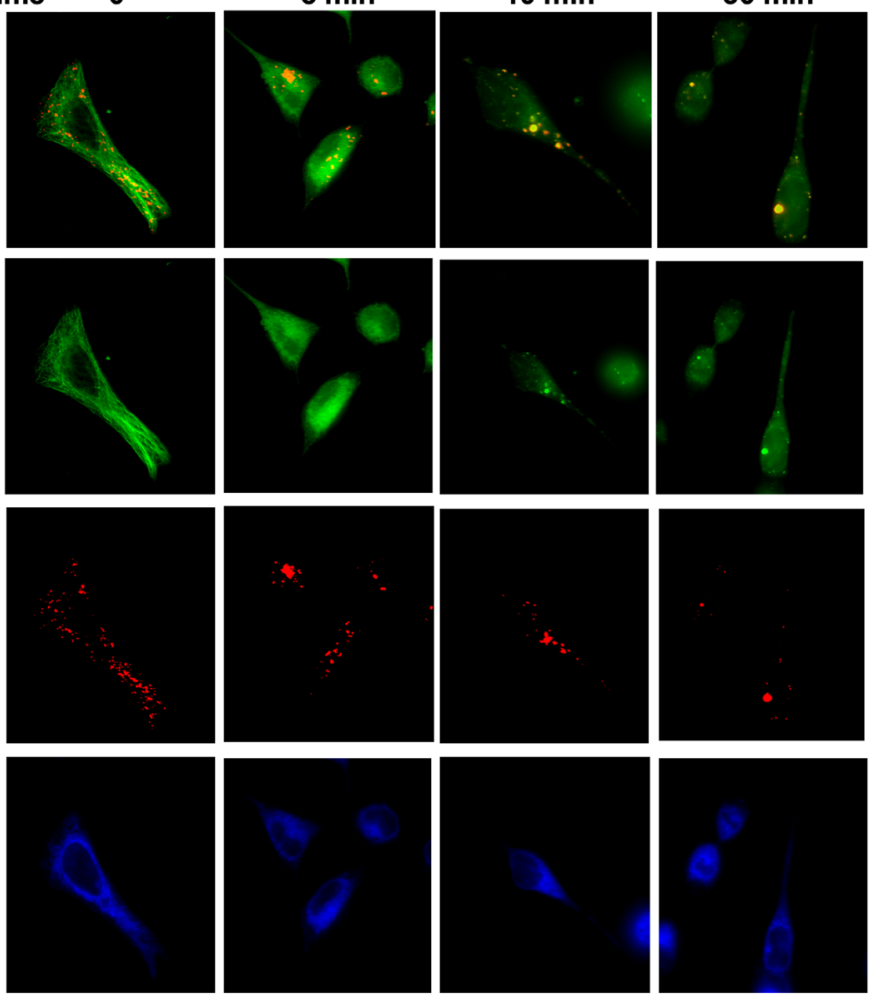

PTX-488 lysosomes ER

Fig. 6 Re-localization of fluorescence labeled Taxol to lysosomes following ultrasound. A Breast and ovarian cancer cells were added with fluorescence labeled Taxol analog (488-PTX) (1 nM) and Lyso-marker for $60 \mathrm{~min}$. The cells on tissue culture dish were exposed to ultrasound (+ US, $40 \mathrm{KHz}, 1.0 \mathrm{~W} / \mathrm{cm}^{2}$ ) for $5 \mathrm{~min}$. Representative 488-PTX images were taken before (control) and after exposure to ultrasound. The signals from 488-PTX and Lyso-Marker were combined/overlaid. An example of A2780 cells is shown. B Cells incubated with fluorescence labeled Taxol analog (488-PTX) (1 nM), ER-Tracker'M, and Lysomarker (BioTracker LYSO-TP Live Cell Dye) markers for 60 min before exposure to ultrasound for 5 min. After exposure to ultrasound at time 0 (no ultrasound), 5, 10, $30 \mathrm{~min}$, the cells were imaged. Representative images of OVCAR5 cells are shown

use higher frequency ultrasound to counter paclitaxel cytotoxicity can be found, and would be useful in certain medical applications as well.
Our finding may have some implications for clinical practice. Since ultrasound disrupts the cellular cytoskeleton, it could interfere with paclitaxel efficacy as a 
chemotherapeutic agent. Caution in using ultrasound to image and monitor tumors following paclitaxel treatment might be warranted, though it is not investigated if the energy level used would be sufficient to break microtubule bundles. At the least, the schedule of imaging should be adjusted to minimize potentially interfering with paclitaxel activity. Still, ultrasound used in diagnostic imaging has low intensity, and the power of the ultrasound waves may not be significant to interfere with drug activity. Additionally, focused and restricted low intensity ultrasound may be applied to prevent toxicity in tissues and organs that are unintentionally exposed to paclitaxel during systemic chemotherapy. In this aspect, it may be interesting to determine if low intensity ultrasound can also reduce cytotoxicity in neuronal cells. If so, low intensity ultrasound might be used to prevent peripheral neuropathy, which is a dose limiting factor in the use of paclitaxel in cancer treatment. Similarly, if ultrasound can reverse paclitaxel cytotoxicity on the cells of hair follicles, a potential treatment for another detrimental side effect of paclitaxel chemotherapy, alopecia, may be resolved by using ultrasound.

We did not observed any killing or suppressive effects of ultrasound shock waves at the level of $1 \mathrm{~W} / \mathrm{cm}^{2}$ on cells in culture. This is consistent with the low risk and widely use of low intensity ultrasound to treat various medical issues. In some experiments, a brief exposure to ultrasound was observed to increase slightly the cell growth during the following 2 days. Likely a brief exposure of cells to ultrasound stimulates cellular growth signaling pathways, such as reported stimulation of MAPK activity and cell proliferation by low intensity ultrasound [66].

We speculate that ultrasound is effective to eliminate cytotoxicity at time only when free paclitaxel in the environment become minimal. Thus, the amount of paclitaxel added and the time for the cells to sequester all paclitaxel will determine the ability of ultrasound exposure to remove paclitaxel-induced cell death and growth suppression. Paclitaxel binds to beta-tubulin with a high affinity, and in the presence of paclitaxel, nearly $80-90 \%$ of cellular tubulin becomes polymerized, whereas normally around $50 \%$ of cellular tubulin is present as a heterodimer [67]. Additionally, paclitaxel is extremely hydrophobic, and likely the molecules rapidly become associated with proteins or other cellular components. Thus, when only a low concentration of paclitaxel is added, paclitaxel likely is depleted in a short time span.

A previous study observed that a short-term exposure of cancer cells to paclitaxel has a long-lasting inhibitory activity [65]. When associated with tubulin, paclitaxel can stabilize the microtubule filaments over 2-3 days, resulting in cell death. However, when disrupted by the physical force exerted by ultrasound shock waves, the tubulins and the bound paclitaxel undergo degradation (Fig. 7). The microtubules re-established are not associated with paclitaxel, thus ultrasound exposure eliminates the effect of paclitaxel on microtubules. Consequently,

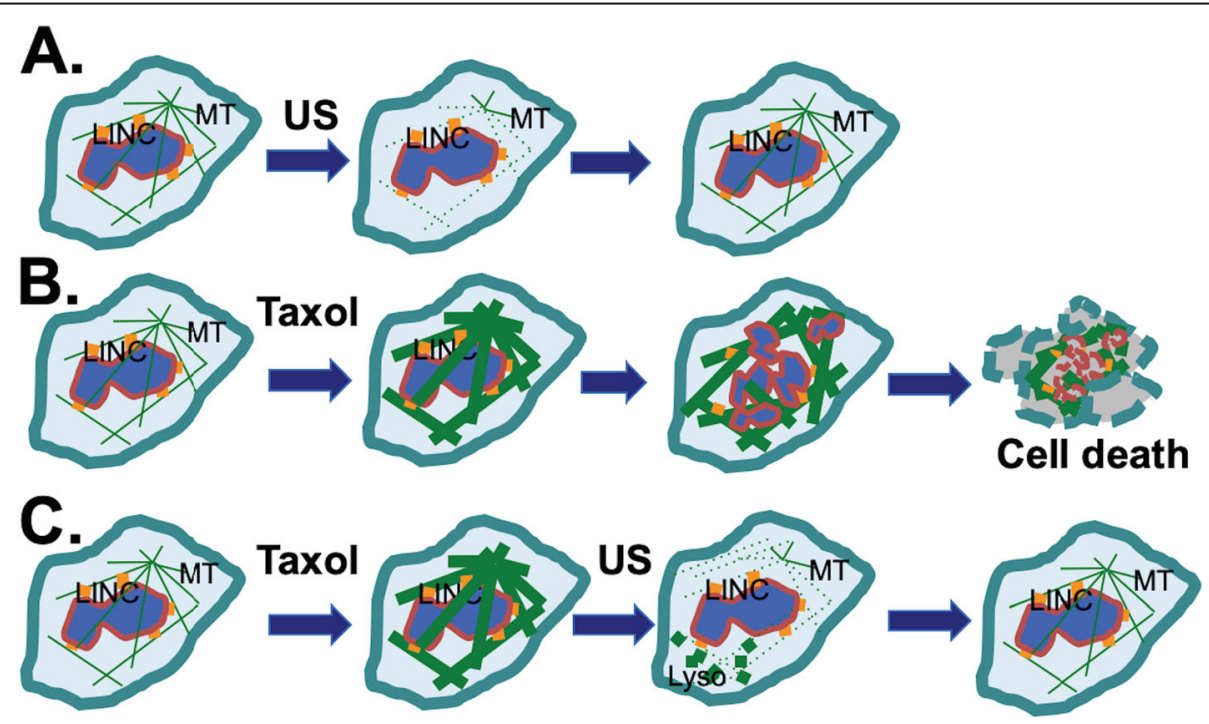

Fig. 7 Concept: Ultrasound reverses cytotoxicity by disrupting rigid microtubule filaments induced by Taxol treatment of proliferating cells. Microtubule (MT) bundles are radiated from the organizing center and associate with the nuclear envelope through LINC (LInking Nuclear and Cytoplasmic) complexes. A Ultrasound (US) is known to transiently disrupt microtubule networks, which reform in a few $(1,2) \mathrm{h}$. B Taxol induces rigid microtubule filaments that lead to growth arrest and subsequent cell death. $\mathbf{C}$ We suggest a mechanism through which ultrasound reverses cytotoxicity by disrupting rigid microtubule filaments induced by Taxol. The Taxol-bound microtubule fragments and tubulins are relocated to lysosomes (Lyso) for degradation (illustrated by the bold dots), and tubulins without bound Taxol form a new microtubule network. Thus, a brief ultrasound exposure is able to eliminate the impact of paclitaxel on microtubules, reversing the cytotoxicity 
the cytotoxicity of paclitaxel on the cancer cells is lessened. A model explains this observation (Fig. 7).

Microtubules, or tubulins are stable proteins with long cellular half-life $[68,69]$. Several studies report on the turn over and degradation of tubulin by cathepsin $\mathrm{D}$ proteasomes pathways [70, 71], but not the lysosomal pathway [71]. Our current finding that paclitaxel-bound microtubule fragments or tubulin monomers are degraded through the lysosomal pathway appears inconsistent with previous findings. However, paclitaxelbound microtubule fragments generated following disruption by ultrasound shock waves are likely processed through a different pathway than heterodimeric tubulins. Future investigations will determine the mechanism of how ultrasound generated microtubule fragments are delivered to lysosomes.

The cellular homeostasis of tubulins is tightly regulated to ensure the presence of a constant level of tubulins for cellular function [68]. The production of alpha- and beta-tubulins is coordinated [69], and the transcription and synthesis of alpha and beta tubulin is regulated by unpolymerized tubulins [72], which participate in the transcription complex [73]. Paclitaxel may stimulate tubulin polymerization and reduces the cellular level of free tubulins, and thus increase tubulin synthesis. This newly generated tubulin would bind and sequester paclitaxel.

The current finding that a brief exposure to ultrasound reverses paclitaxel cytotoxicity by itself will not be useful for using ultrasound to enhance chemotherapy, since generally one would hope to increase cytotoxicity of the drug on cancer cells. However, the finding may caution the exposure of patients immediately after paclitaxel chemotherapy administration, which may be used for monitoring purposes in some cases. Additionally, the finding may be useful to prevent paclitaxel-caused neuronal toxicity caused by paclitaxel chemotherapy. Thus, low intensity ultrasound may be useful to prevent paclitaxel-induced peripheral neuropathy or alopecia, if the observation in cancer cells is also found to be applicable to neuronal cells or cells of hair follicles.

\section{Supplementary Information}

The online version contains supplementary material available at https://doi. org/10.1186/s12885-021-08722-7.

Additional file 1: Supplementary Figure 1. Disruption of microtubule cytoskeleton in OVCAR3 ovarian cancer cells. (A) OVCAR3 ovarian cancer cells on tissue culture dish were exposed to ultrasound (+ US, $40 \mathrm{KHz}, 3$ W/ $\mathrm{cm}^{2}$ ) for $5 \mathrm{~min}$. The cells were then were fixed and processed for immunostaining for alpha-tubulin and Lamin A/C. (B) OVCAR3 cells on tissue culture dish were exposed to ultrasound (+ US, $40 \mathrm{KHz}, 1 \mathrm{~W} / \mathrm{cm}^{2}$ ) for $5 \mathrm{~min}$ and then were fixed and processed for analyses by immunofluorescence microscopy for alpha tubulins and Lamin B. Supplementary Figure 2. Disruption of fluorescence labeled Taxol bound microtubule cytoskeleton in cancer cells by ultrasound. Breast (MCF-7) and ovarian (OVCAR3, OVCAR8) cancer cells were added with fluorescence labeled Taxol analog (488-PTX) (1 nM) for $60 \mathrm{~min}$. The cells on tissue culture dish were exposed to ultrasound ( $+\mathrm{US}, 40 \mathrm{KHz}, 1.0 \mathrm{~W} / \mathrm{cm}^{2}$ ) for $5 \mathrm{~min}$. Representative 488-PTX images were taken before (control) and after exposure to ultrasound. Supplementary Figure 3. Disruption and progressively elimination of fluorescence labeled Taxol bound microtubule cytoskeleton in ovarian cancer cells by ultrasound. OVCAR3 ovarian cancer cells were added with fluorescence labeled Taxol analog (488-PTX) (1 nM) for $60 \mathrm{~min}$. The cells on tissue culture dish were exposed to ultrasound (+ US, $40 \mathrm{KHz}, 1.0 \mathrm{~W} / \mathrm{cm}^{2}$ ) for $5 \mathrm{~min}$. Representative 488-PTX images were taken before (control) and after exposure to ultrasound for 0, 10, 20, and $30 \mathrm{~min}$.

\section{Acknowledgments}

We also thank our colleagues, including Drs. Sophia George and Wensi Tao for their conceptual discussions and technical advice in the course of the experiments. We thank our colleagues for advice and discussion during the course of the experiments and the preparation of the manuscript. Our student interns, including Mariana Lopes dos Santos and Justin Leal, contributed to the early part of the research.

\section{Authors' contributions}

$J B$ and $R B$ made the original observation and obtained the initial results. $X X X, E R S$, and CA further developed concepts, and designed and planned the experiments. CA generated most of the data. SL assisted in performing many experiments. CA and XXX performed data analyses and prepared the initial drafts of the manuscript. All authors, especially ERS, contributed to revising and editing the manuscript. The author(s) read and approved the final manuscript.

\section{Funding}

This work was partially supported by funds from grant NICHD R03HD071244 (E.R.S.), concept awards BC097189 and BC076832 from Department of Defense (USA). Grants R01 CA230916, R01 CA095071, R01 CA099471, and CA79716 to X-X Xu from NCl, NIH also contributed to the studies. Lastly, internal funding from Sylvester Comprehensive Cancer Center/University of Miami was the main support for this work.

\section{Availability of data and materials}

Cell lines (some are available commercially from ATCC), more detailed lab procedures and protocols, and the datasets used and/or analyzed during the current study are available from the corresponding author on reasonable request.

\section{Declarations}

Ethics approval and consent to participate Not applicable.

\section{Consent for publication}

Not applicable.

\section{Competing interests}

The authors declare no competing interests.

\section{Author details}

${ }^{1}$ Department of Radiation Oncology, Sylvester Comprehensive Cancer Center, University of Miami Miller School of Medicine, Papanicolaou Building, Room 415 [M877], 1550 NW 10th Avenue, Miami, FL 33136, USA. ${ }^{2}$ HHMI High School Scholars Program, Department of Undergraduate Research and Community Outreach, University of Miami, Miami, FL 33146, USA. ${ }^{3}$ Department of Cell Biology, University of Miami Miller School of Medicine, Miami, FL 33136, USA.

Received: 16 March 2021 Accepted: 24 August 2021

Published online: 01 September 2021

\section{References}

1. Barbuti AM, Chen ZS. Paclitaxel through the ages of anticancer therapy: exploring its role in Chemoresistance and radiation therapy. Cancers (Basel). 2015;7(4):2360-71. https://doi.org/10.3390/cancers7040897. 
2. Jordan MA, Wilson L. Microtubules as a target for anticancer drugs. Nat Rev Cancer. 2004;4(4):253-65. https://doi.org/10.1038/nrc1317.

3. Wani MC, Horwitz SB. Nature as a remarkable chemist: a personal story of the discovery and development of Taxol. Anti-Cancer Drugs. 2014;25(5):4827. https://doi.org/10.1097/CAD.0000000000000063.

4. Zhao Y, Mu X, Du G. Microtubule-stabilizing agents: new drug discovery and cancer therapy. Pharmacol Ther. 2016;162:134-43. https://doi.org/10.101 6/j.pharmthera.2015.12.006.

5. Runowicz CD, Wiernik PH, Einzig Al, Goldberg GL, Horwitz SB. Taxol in ovarian cancer. Cancer. 1993;71(4 Suppl):1591-6. https://doi.org/10.1002/ cncr.2820710442.

6. Yang $\mathrm{CH}$, Horwitz SB. Taxol ${ }^{\oplus}$ : the first microtubule stabilizing agent. Int J Mol Sci. 2017;18(8):1733.

7. Bookman MA. Optimal primary therapy of ovarian cancer. Ann Oncol. 2016; 27(Suppl 1):i58-62. https://doi.org/10.1093/annonc/mdw088.

8. Baird RD, Tan DS, Kaye SB. Weekly paclitaxel in the treatment of recurrent ovarian cancer. Nat Rev Clin Oncol. 2010;7(10):575-82. https://doi.org/10.103 8/nrclinonc.2010.120

9. Baker W. Salvage therapy for recurrent epithelial ovarian cancer. Hematol Oncol Clin North Am. 2003;17(4):977-88. https://doi.org/10.1016/S08898588(03)00057-1.

10. Dunder I, Berker B, Atabekoglu C, Bilgin T. Preliminary experience with salvage weekly paclitaxel in women with advanced recurrent ovarian carcinoma. Eur J Gynaecol Oncol. 2005;26(1):79-82.

11. Jain A, Dubashi B, Reddy KS, Jain P. Weekly paclitaxel in ovarian cancer-the latest success story. Curr Oncol. 2011;18(1):16-7. https://doi.org/10.3747/co. v18i1.680.

12. Canta A, Chiorazzi A, Cavaletti G. Tubulin: a target for antineoplastic drugs into the cancer cells but also in the peripheral nervous system. Curr Med Chem. 2009;16(11):1315-24. https://doi.org/10.2174/092986709787846488.

13. Kudlowitz D, Muggia F. Clinical features of taxane neuropathy. Anti-Cancer Drugs. 2014;25(5):495-501. https://doi.org/10.1097/CAD.0000000000000051.

14. Gornstein E, Schwarz TL. The paradox of paclitaxel neurotoxicity: Mechanisms and unanswered questions. Neuropharmacology. 2014;76(Pt A): 175-83

15. Velasco R, Bruna J. Taxane-induced peripheral neurotoxicity. Toxics. 2015; 3(2):152-69. https://doi.org/10.3390/toxics3020152.

16. Griffiths C, Kwon N, Beaumont JL, Paice JA. Cold therapy to prevent paclitaxel-induced peripheral neuropathy. Support Care Cancer. 2018;26(10): 3461-9. https://doi.org/10.1007/s00520-018-4199-9.

17. Hanai A, Ishiguro H, Sozu T, Tsuda M, Yano I, Nakagawa T, et al. Effects of cryotherapy on objective and subjective symptoms of paclitaxel-induced neuropathy: prospective self-controlled trial. J Natl Cancer Inst. 2018;110(2): 141-8. https://doi.org/10.1093/jnci/djx178.

18. Mielke S, Sparreboom A, Mross K. Peripheral neuropathy: a persisting challenge in paclitaxel-based regimes. Eur J Cancer. 2006;42(1):24-30. https://doi.org/10.1016/j.ejca.2005.06.030.

19. Staff NP, Fehrenbacher JC, Caillaud M, Damaj MI, Segal RA, Rieger S. Pathogenesis of paclitaxel-induced peripheral neuropathy: a current review of in vitro and in vivo findings using rodent and human model systems. Exp Neurol. 2020;324:113121. https://doi.org/10.1016/j.expneurol.201 9.113121 .

20. Freites-Martinez A, Chan D, Sibaud V, Shapiro J, Fabbrocini G, Tosti A, et al. Assessment of quality of life and treatment outcomes of patients with persistent Postchemotherapy alopecia. JAMA Dermatol. 2019;155(6):724-8. https://doi.org/10.1001/jamadermatol.2018.5071.

21. Prevezas C, Matard B, Pinquier L, Reygagne P. Irreversible and severe alopecia following docetaxel or paclitaxel cytotoxic therapy for breast cancer. Br J Dermatol. 2009;160(4):883-5. https://doi.org/10.1111/j.13 65-2133.2009.09043.x.

22. Rossi A, Fortuna MC, Caro G, Pranteda G, Garelli V, Pompili U, et al. Chemotherapy-induced alopecia management: clinical experience and practical advice. J Cosmet Dermatol. 2017;16(4):537-41. https://doi.org/1 $0.1111 /$ jocd. 12308

23. Schiff PB, Fant J, Horwitz SB. Promotion of microtubule assembly in vitro by taxol. Nature. 1979;277(5698):665-7. https://doi.org/10.1038/277665a0.

24. Schiff PB, Horwitz SB. Taxol stabilizes microtubules in mouse fibroblast cells. Proc Natl Acad Sci U S A. 1980;77(3):1561-5. https://doi.org/10.1073/pnas. 77.3.1561.

25. Bhalla KN. Microtubule-targeted anticancer agents and apoptosis. Oncogene. 2003;22(56):9075-86. https://doi.org/10.1038/sj.onc.1207233.
26. Blagosklonny MV, Fojo T. Molecular effects of paclitaxel: myths and reality (a critical review). Int J Cancer. 1999;83(2):151-6. https://doi.org/10.1002/(SICI)1 097-0215(19991008)83:2<151::AID-IJC1>3.0.CO;2-5.

27. Morse DL, Gray H, Payne CM, Gillies RJ. Docetaxel induces cell death through mitotic catastrophe in human breast cancer cells. Mol Cancer Ther. 2005:4(10):1495-504. https://doi.org/10.1158/1535-7163.MCT-05-0130.

28. Weaver BA. How Taxol/paclitaxel kills cancer cells. Mol Biol Cell. 2014;25(18): 2677-81. https://doi.org/10.1091/mbc.e14-04-0916.

29. Horwitz SB. Taxol (paclitaxel): mechanisms of action. Ann Oncol. 1994; 5(Suppl 6):S3-6.

30. Field JJ, Kanakkanthara A, Miller JH. Microtubule-targeting agents are clinically successful due to both mitotic and interphase impairment of microtubule function. Bioorg Med Chem. 2014;22(18):5050-9. https://doi. org/10.1016/j.bmc.2014.02.035.

31. Komlodi-Pasztor E, Sackett D, Wilkerson J, Fojo T. Mitosis is not a key target of microtubule agents in patient tumors. Nat Rev Clin Oncol. 2011;8(4):24450. https://doi.org/10.1038/nrclinonc.2010.228

32. Komlodi-Pasztor E, Sackett DL, Fojo AT. Inhibitors targeting mitosis: tales of how great drugs against a promising target were brought down by a flawed rationale. Clin Cancer Res. 2012;18(1):51-63. https://doi.org/10.1158/1 078-0432.CCR-11-0999.

33. Mitchison TJ, Pineda J, Shi J, Florian S. Is inflammatory micronucleation the key to a successful anti-mitotic cancer drug? Open Biol. 2017;7(11):170182. https://doi.org/10.1098/rsob.170182

34. Xie SB, Ogden A, Aneja R, Zhou J. Microtubule-binding proteins as promising biomarkers of paclitaxel sensitivity in Cancer chemotherapy. Med Res Rev. 2016;36(2):300-12. https://doi.org/10.1002/med.21378.

35. Orr GA, Verdier-Pinard P, McDaid H, Horwitz SB. Mechanisms of Taxol resistance related to microtubules. Oncogene. 2003;22(47):7280-95. https:// doi.org/10.1038/sj.onc.1206934.

36. Miller DL, Smith NB, Bailey MR, Czarnota GJ, Hynynen K, Makin IR, et al. Overview of therapeutic ultrasound applications and safety considerations. J Ultrasound Med. 2012;31(4):623-34. https://doi.org/10. 7863/jum.2012.31.4.623.

37. Robertson VJ, Baker KG. A review of therapeutic ultrasound: effectiveness studies. Phys Ther. 2001:81(7):1339-50 Centre for Reviews and Dissemination (UK).

38. ter Haar G. Therapeutic applications of ultrasound. Prog Biophys Mol Biol. 2007;93(1-3):111-29. https://doi.org/10.1016/j.pbiomolbio.2006.07.005.

39. Ahmadi F, McLoughlin IV, Chauhan S, ter-Haar G. Bio-effects and safety of low-intensity, low-frequency ultrasonic exposure. Prog Biophys Mol Biol. 2012;108(3):119-38. https://doi.org/10.1016/j.pbiomolbio.2012.01.004.

40. Dalecki D. Mechanical bioeffects of ultrasound. Annu Rev Biomed Eng. 2004 6(1):229-48. https://doi.org/10.1146/annurev.bioeng.6.040803.140126.

41. Robertson VJ, Ward AR. Subaqueous ultrasound: $45 \mathrm{kHz}$ and $1 \mathrm{MHz}$ machines compared. Arch Phys Med Rehabil. 1995;76(6):569-75. https://doi.org/10.101 6/S0003-9993(95)80513-3.

42. Reher P, Doan N, Bradnock B, Meghji S, Harris M. Therapeutic ultrasound for osteoradionecrosis: an in vitro comparison between $1 \mathrm{MHz}$ and $45 \mathrm{kHz}$ machines. Eur J Cancer. 1998;34(12):1962-8. https://doi.org/10.1016/S09598049(98)00238-X

43. Doan N, Reher P, Meghji S, Harris M. In vitro effects of therapeutic ultrasound on cell proliferation, protein synthesis, and cytokine production by human fibroblasts, osteoblasts, and monocytes. J Oral Maxillofac Surg. 1999:57(4):409-19; discussion 420. https://doi.org/10.1016/S0278-2391 (99)90281-1.

44. Reher P, Doan N, Bradnock B, Meghji S, Harris M. Effect of ultrasound on the production of IL-8, basic FGF and VEGF. Cytokine. 1999;11(6):416-23. https:// doi.org/10.1006/cyto.1998.0444.

45. Barnett SB. Thresholds for nonthermal bioeffects: theoretical and experimental basis for a threshold index. Ultrasound Med Biol. 1998;24: S41-9.

46. Fischell TA, Abbas MA, Grant GW, Siegel RJ. Ultrasonic energy. Effects on vascular function and integrity. Circulation. 1991;84(4):1783-95. https://doi. org/10.1161/01.CIR.84.4.1783

47. Scarponi C, Nasorri F, Pavani F, Madonna S, Sestito R, Simonacci M, et al. Low-frequency low-intensity ultrasounds do not influence the survival and immune functions of cultured keratinocytes and dendritic cells. J Biomed Biotechnol. 2009;2009:193260.

48. Sunny Y, Bawiec CR, Nguyen AT, Samuels JA, Weingarten MS, Zubkov LA, et al. Optimization of un-tethered, low voltage, $20-100 \mathrm{kHz}$ flexural 
transducers for biomedical ultrasonics applications. Ultrasonics. 2012;52(7): 943-8. https://doi.org/10.1016/j.ultras.2012.03.004.

49. Abramavičius $\mathrm{S}$, Volkevičiūtè $\mathrm{A}$, Tunaitytè A, Venslauskas $\mathrm{M}$, Bubulis $\mathrm{A}$, Bajoriūnas $\mathrm{V}$, et al. Low-frequency $(20 \mathrm{kHz})$ ultrasonic modulation of drug action. Ultrasound Med Biol. 2020;46(11):3017-31. https://doi.org/10.1016/j. ultrasmedbio.2020.07.002.

50. lida K, Luo H, Hagisawa K, Akima T, Shah PK, Naqvi TZ, et al. Noninvasive low-frequency ultrasound energy causes vasodilation in humans. J Am Coll Cardiol. 2006;48(3):532-7. https://doi.org/10.1016/j.jacc.2006.03.046.

51. Samuels JA, Weingarten MS, Margolis DJ, Zubkov L, Sunny Y, Bawiec $C R$, et al. Low-frequency $(<100 \mathrm{kHz})$, low-intensity $(<100 \mathrm{~mW} / \mathrm{cm}$ (2)) ultrasound to treat venous ulcers: a human study and in vitro experiments. J Acoust Soc Am. 2013;134(2):1541-7. https://doi.org/10.1121/1.4812875.

52. Hrazdira I, Skorpıkova J, Dolnıkova M. Ultrasonically induced alterations of cultured tumour cells. Eur J Ultrasound. 1998;8(1):43-9. https://doi.org/10.1 016/50929-8266(98)00049-4.

53. Adler J, Necas O, Hrazdira I. Dissassembly of microtubules due to low intensity ultrasound. Folia Biol (Praha). 1993;39(1):55-7.

54. Samandari M, Abrinia K, Mokhtari-Dizaji M, Tamayol A. Ultrasound induced strain cytoskeleton rearrangement: an experimental and simulation study. J Biomech. 2017;60:39-47. https://doi.org/10.1016/j.jbiomech.2017.06.003.

55. Skorpıkova J, Dolnıkova M, Hrazdira I, Janisch R. Changes in microtubules and microfilaments due to a combined effect of ultrasound and cytostatics in HeLa cells. Folia Biol (Praha). 2001;47(4):143-7.

56. Cachon J, Cachon M, Bruneton J-N. An ultrastructural study of the effects of very high frequency ultrasound on a microtubular system (Axopods of a heliozoan). Biol Cell. 1981:40:69-72.

57. Udroiu I, Marinaccio J, Bedini A, Giliberti C, Palomba R, Sgura A. Genomic damage induced by $1-\mathrm{MHz}$ ultrasound in vitro. Environ Mol Mutagen. 2018; 59(1):60-8. https://doi.org/10.1002/em.22124.

58. Emoto M. Development of a Cancer treatment with the concomitant use of low-intensity ultrasound: entering the age of simultaneous diagnosis and treatment. Diagnostics (Basel). 2014;4(2):47-56. https://doi.org/10.3390/dia gnostics4020047.

59. Capo-chichi CD, Roland IH, Vanderveer L, Bao R, Yamagata $T$, Hirai H, et al. Anomalous expression of epithelial differentiation-determining GATA factors in ovarian tumorigenesis. Cancer Res. 2003;63(16):4967-77.

60. Hamilton TC, Young RC, Louie KG, Behrens BC, McKoy WM, Grotzinger KR, et al. Characterization of a xenograft model of human ovarian carcinoma which produces ascites and intraabdominal carcinomatosis in mice. Cancer Res. 1984;44(11):5286-90

61. Capo-chichi CD, Cai KQ, Simpkins F, Ganjei-Azar P, Godwin AK, Xu XX. Nuclear envelope structural defects cause chromosomal numerical instability and aneuploidy in ovarian cancer. BMC Med. 2011;9(1):28. https:// doi.org/10.1186/1741-7015-9-28.

62. Capo-Chichi CD, Yeasky TM, Smith ER, Xu XX. Nuclear envelope structural defect underlies the main cause of aneuploidy in ovarian carcinogenesis. BMC Cell Biol. 2016;17(1):37. https://doi.org/10.1186/s12 860-016-0114-8.

63. Smith ER, Meng Y, Moore R, Tse JD, Xu AG, Xu XX. Nuclear envelope structural proteins facilitate nuclear shape changes accompanying embryonic differentiation and fidelity of gene expression. BMC Cell Biol. 2017;18(1):8. https://doi.org/10.1186/s12860-017-0125-0.

64. Smith ER, Leal J, Amaya C, Li B, Xu XX. Nuclear Lamin A/C Expression Is a Key Determinant of Paclitaxel Sensitivity. Mol Cell Biol. 2021:00648-20. https://doi.org/10.1128/MCB.00648-20 Online ahead of print.

65. Michalakis J, Georgatos SD, de Bree E, Polioudaki H, Romanos J, Georgoulias $V$, et al. Short-term exposure of cancer cells to micromolar doses of paclitaxel, with or without hyperthermia, induces long-term inhibition of cell proliferation and cell death in vitro. Ann Surg Oncol. 2007;14(3):1220-8. https://doi.org/10.1245/s10434-006-9305-4.

66. Gao Q, Walmsley AD, Cooper PR, Scheven BA. Ultrasound stimulation of different dental stem cell populations: role of mitogen-activated protein kinase signaling. J Endod. 2016;42(3):425-31. https://doi.org/10.1016/j.joen.2 015.12.019.

67. Zhai Y, Borisy GG. Quantitative determination of the proportion of microtubule polymer present during the mitosis-interphase transition. J Cell Sci. 1994;107(Pt 4):881-90. https://doi.org/10.1242/jcs.107.4.881.

68. Ben-Ze'ev A, Farmer SR, Penman S. Mechanisms of regulating tubulin synthesis in cultured mammalian cells. Cell. 1979;17(2):319-25. https://doi. org/10.1016/0092-8674(79)90157-0.
69. Gonzalez-Garay ML, Cabral F. Overexpression of an epitope-tagged betatubulin in Chinese hamster ovary cells causes an increase in endogenous alpha-tubulin synthesis. Cell Motil Cytoskeleton. 1995;31(4):259-72. https:// doi.org/10.1002/cm.970310403.

70. Huff LM, Sackett DL, Poruchynsky MS, Fojo T. Microtubule-disrupting chemotherapeutics result in enhanced proteasome-mediated degradation and disappearance of tubulin in neural cells. Cancer Res. 2010;70(14):5870-9. https://doi.org/10.1158/0008-5472.CAN-09-4281.

71. Johnson GV, Litersky JM, Whitaker JN. Proteolysis of microtubule-associated protein 2 and tubulin by cathepsin D. J Neurochem. 1991;57(5):1577-83. https://doi.org/10.1111/j.1471-4159.1991.tb06354.x.

72. Caron JM, Jones AL, Rall LB, Kirschner MW. Autoregulation of tubulin synthesis in enucleated cells. Nature. 1985;317(6038):648-51.

73. Lin Z, Gasic I, Chandrasekaran V, Peters N, Shao S, Mitchison TJ, et al. TTC5 mediates autoregulation of tubulin via mRNA degradation. Science. 2020; 367(6473):100-4. https://doi.org/10.1126/science.aaz4352.

\section{Publisher's Note}

Springer Nature remains neutral with regard to jurisdictional claims in published maps and institutional affiliations.

\section{Ready to submit your research? Choose BMC and benefit from:}

- fast, convenient online submission

- thorough peer review by experienced researchers in your field

- rapid publication on acceptance

- support for research data, including large and complex data types

- gold Open Access which fosters wider collaboration and increased citations

- maximum visibility for your research: over $100 \mathrm{M}$ website views per year

At BMC, research is always in progress.

Learn more biomedcentral.com/submissions 